\title{
CANTIGA 10's ROSE-MARY: \\ SUPERLATIVE ALLEGORY OF BEAUTY AND POWER ${ }^{1}$
}

\author{
Abraham Quintanar
}

The second loor to the Virgin in Cantigas de Santa Maria ${ }^{2}$ appears as Cantiga 10 and is most important since it presents for the first time a figurative literary and graphic image of the subject of an entire collection of illustrated songs. Starting with this loor's refrain, Alfonso X, el Sabio, defines Mary's standing concerning merit, station, and femininity, including her rank among women, as he exalts:

Rosa das rosas e fror das frores

Dona das donas, sennor de Sennores. ${ }^{3}$ (10:1-2)

[Rose of roses and Flower of flowers

Dame of dames, Lady of ladies.] $]^{4}$

The beginning of the refrain, "Rosa das rosas," brings to mind Marina Warner's watershed study on the myth and cult of the Virgin Mary; its title, Alone of All Her Sex, could easily mean "Woman of women," signifying Mary as the supreme example of womanhood. ${ }^{5}$ Despite the

\footnotetext{
${ }^{1}$ A previous version of this essay was presented at the $120^{\text {th }}$ Annual Convention of the MLA, in the session "Females in Flower: Marguerites, Roses, and the Flower and Leaf as Courtly Cults," sponsored by the International Courtly Literature Society.

${ }^{2}$ Hereafter CSM, especially when referring to the text. In the CSM, every $10^{\text {th }}$ cantiga is a loor [laud], or song of praise to the Virgin.

${ }^{3}$ For brevity's sake, I will cite verses from the songs in the text by song and line numbers, as here, where 10:1-2 refers to Cantiga 10, verses 1-2, in Alfonso's Cantigas de Santa Maria: Edición Facsímil del Códice T.I.1 de la biblioteca de San Lorenzo el Real de El Escorial, 2 vols (Madrid: Edilán 1979). Unless otherwise noted, all citations of songs, cantigas, will be from the facsimile edition.

${ }^{4}$ Unless otherwise noted, all translations of Galician-Portuguese are mine. However, I do consult other translations, most notably those of Kathleen Kulp-Hill in Alfonso X, el Sabio, Songs of Holy Mary of Alfonso X, the Wise: A Translation of the Cantigas de Santa Maria (Tempe: Arizona Center for Medieval and Renaissance Studies, 2000.)

${ }^{5}$ Despite concurring that there is no woman exalted like Mary, as Alfonso also does, Warner does not treat Cantiga 10 nor the Cantigas de Santa Maria as a corpus that strives to make Mary present. Warner only refers specifically to Alfonso's work commenting that Alfonso "turned Gautier's miracles into Spanish songs" (154), and mentioning parenthetically that the thirteenth-century Theophilus tale, Alfonso's Cantiga 2, appears in illuminated manuscripts "(as in Alfonso el Sabio's Cantigas)," (324), Marina Warner. Alone of all Her Sex (New York: Knopf, 1976).
} 
centuries that separate them, both Warner and Alfonso X highlight Mary's singularity by using the same superlative syntactic structure, one that establishes a theme that when glossed reveals an allegorical representation of a system of religious empire, whose power relegates earthbound woman, ${ }^{6}$ not given over to Marian ideology, to a spiritually deprived condition and an inferior political state. ${ }^{7}$

The rubricated incipit that introduces this cantiga imbues the allegorical representation in this work with ethical qualities of the ideology propagated in sensual courtly lyric by which the poetic voice can validate its posture. Despite the claim of the rubric to Cantiga 10 that this song is a praise to Mary- “[E]sta é de loor de Santa Maria, com' é fermosa, e bõa e á gran poder" [This is in praise of Holy Mary, how (She) is beautiful, good, and powerful] - the poet or troubadour does not praise Her directly. Instead, he sings Her praises to the reader-listener who witnesses Alfonso's role-relation to the unattainable Mary. This indirect communiqué underscores an ambiguous relationship with Holy Mary. On the one hand, Alfonso, as a vassal, pledges his service, "esta dona que tenno por Sennor" [10:18, this dame I have as my liege], while on the other, as a poet he aspires to be her exclusive troubadour, "de que quero ser trobador" [10:19, whose troubadour I desire to be]. Not yet having received her rewards, he cannot yet count himself as an accepted lover, as her entendedor. ${ }^{8}$ It is not until the last stanza of Cantiga 130 that Alfonso can be said to proclaim himself Mary's entendedor:

\footnotetext{
6 "Earthbound," restricted to the earth or worldly concerns ("earthbound, adj.1," $O E D$ Online, Oxford University Press, July 2018, www.oed.com/view/Entry/273638. Accessed 2 November 2018). Holy Mary, however, has concerns in heavenly and earthly spheres.

${ }^{7}$ We use the simple definition of allegory as a "'symbolic narrative' in which the major features of the movement of the narrative are held to refer symbolically to some action or situation"; we include the "important function in imperial discourse in which paintings and statues have often been created," or can be seen as, "allegories of imperial power" (Bill Ashcroft, Gareth Griffiths and Helen Tiffin, eds., Post-Colonial Studies: the Key Concepts [London; New York: Routledge, 2000], 9-10). In the present study, we appropriate allegory and use it to respond to the "allegorical representation" of religious ideology, reflected in Mariology as well as in the concept of the Holy Roman Emperorship, as "imperial dominance" of woman.

${ }^{8}$ I rely on Cropp's Occitan concept of entendedor: one who has, generally speaking, received a favor, has been welcomed to be close to the lady, who has the right to employ the terms midons and ma domna when speaking about his lady, and above all, strives to better himself so that he may be closer to her [a, en gènèral, reçu une faveur, il a été accueilli auprès de la dame, il a le droit d'employer les termes midons et ma domna en parlant de sa dame, il s'occupe surtout de s'améliorer pour s'approcher davantage d'elle]
} 
E poren seu entendedor Serei

en quant' eu uiua, e loarei (10:34-35)

[And so, her entendedor (suitor) I shall be

While I live, and I shall laud (praise) her]

Because of the future tense of the verbs "serei" and "loarei," it is difficult to establish that the poet is presently Mary's lover, since up to now there has been no sign from Mary conferring a preferred status on him. However, "Serei" [I shall be] is the only word in this song that is capitalized mid-line, suggesting emphasis. Adding to this ambiguity is the refrain in Cantiga 130 in which the poet proclaims that "he who desires affection /understanding, let him be a suitor to the Mother of Our Lord" (130:1-2). Here, the double entendre of both "entender" and "entendedor" cannot be lost on Alfonso since, as Jean-Marie d'Heur points out, he is documented as the patron to more Occitan poets than any other royal Peninsular figure. ${ }^{9}$

Since the extant works of twelfth- and thirteenth-century Occitan poets residing in the Iberian Peninsula are overwhelmingly rendered in Occitan only, we can surmise that Occitan was a commonly understood courtly language in Castile. So, when Alfonso declares in the refrain to Cantiga 130,

Quem entender quiser, entendedor seja da madre de nostro sennor

[(Alternately) who a lover wishes to be, let him be

A suitor (lover) of the mother of our lord]

we cannot ignore that in Occitan lyric, the verb "entendre" used as a substantive noun can only mean "love" or "affection" and not "to understand." $" 10$ We also must keep in mind that only an entendedor may

(Cropp, 59). Unless otherwise noted, all translations of Cropp are mine. Glynnis M. Cropp, Le vocabulaire courtois des troubadours de l'époque classique (Geneva: Droz, 1975).

9 The index to Heur's work contains more entries for Alfonso X than any other poet, Occitan or Peninsular. He also dedicates three chapters to him: I: III, III: II, III: III. He also documents the ten years that Guiraut Riquier spent as resident poet, writing only in Occitan, in Alfonso's Castilian Court. Jean-Marie d'Heur, Troubadours d'Oc et troubadours galiciens-portugais (Paris: Funação Calouste Gulbenkian, 1973), ad passim.

10 See Emil Levy, comp., Petit dictionnaire provençal-français, s.v. "entendre" (Heidelberg: Carl Winter, 1973). 
refer to his lady as domna, only he can compose-trobar-songs that show affection, physical attraction and allegiance towards her.

In the loores, songs of affection and praise, Joseph Snow sees Alfonso projecting the "troubadour persona" that permits him "to create and personalize an emotional relationship between poet and subject, between Alfonso and Mary," ${ }^{11}$ though we might add that at this point in the collection, Alfonso is but an aspiring lover. Snow rightfully points out that in characterizing and developing the troubadour persona throughout the CSM, Alfonso "borrows [from the Occitan troubadours] the scheme of stages of candidacy [-fenhedor, pregador, entendedor, and drut-] through which the lover must ascend in order to achieve complete union with the beloved." ${ }^{\prime 2}$ Given this scheme, we might ask: at what stage does the poet find himself in Cantiga 10, the first of the loores? The incipient devotee has not yet declared his love, neither has he directly asked for a sign from Her, nor is he compelled to ask as a pregador would. ${ }^{13}$ Charging the male reader that all should love her, the poet feigns a relationship with Mary as he sings praises of her-clearly not yet her troubadour, as in verse 20 he expresses his aspiration to become one. ${ }^{14}$ Instead, he is the lowest of courtly lovers, a fenhedor, whom Cropp describes as "an incipient and timid lover who does not express his love" directly, ${ }^{15}$ and thus can only aspire, feign, to love his lady. This superlatively lowly poet-lover, who hopes for a sign, is identified in "Prologue A" of the CMS with Alfonso X's poetic voice, the pretender to the Holy Roman Emperorship, ${ }^{16}$ who: "composed [the]

\footnotetext{
${ }^{11}$ Joseph T. Snow, "The central rôle of the troubadour persona of Alfonso X in the Cantigas de Santa Maria,” BHS LVI (1979): 305.

${ }^{12}$ Snow, 310. For a detailed treatment of these four stages see Cropp's Chapter 2: "La dénomination du poète-amoreux," 49-80.

${ }^{13}$ pregador: One who may ask favors from the domna [qui sollicite les faveurs de la dame], Cropp, 54.

14 "de que quero seer trobador" [whose (referring to Mary) troubadour I want to be], Alfonso, Cantiga 10, verse 20.

15 'Le mot fenhedor a en effet signifié 'amoureux timide et debutant,' l'amoureux de ce type ne s'est pas exprimé dans la chanson courtoise. Muet, il a dû cacher son amour : il ne le chante pas lui-même, il ne cherche pas de porte-parole." Cropp, Le vocabularie, 49-54.

${ }^{16}$ This prologue proclaims him by rights to be the Holy Roman Emperor, Alfonso X, el Sabio. Cantigas de Santa María, ed. and trans. Walter Mettman (Madrid: Castalia, 198689), 16-20. According to Mettman, Alfonso maintains his pretensions to the imperial throne from 1257-75 (54). Miguel González Jiménez, in Alfonso X el Sabio (Palencia: Diputación Provincial de Palencia, 1973, 49-68), points out that even though the spring of 1275 brought with it the finality that Alfonso would never be Emperor, it was between 1254 and
} 
songs and melodies which are delightful to sing, each [telling] its own narration" [Fezo cantares e sões, / sabrosos de cantar, / todos de sennas razões, / com' y podedes achar. ${ }^{17}$ Alfonso, powerful enough to lay a claim, however unsuccessfully, to Emperorship, humbles himself before Mary, human and divine, whom he longs to serve exclusively with song (Alfonso, Cantiga 10:20). She is above all women as he becomes an instrument of her power.

Cantiga 10 begins Alfonso's praise of She to whom he pretends with the refrain that introduces the song's theme:

Rosa das rosas e fror das frores,

Dona das donas, sennor de Sennores. (10:1-2)

Typical of the loores, the poem repeats the refrain after each stanza (in quatrains) that glosses the theme. Verse one of the refrain brings to mind verse six, stanza one, of Gautier de Coinci's "1 Chanson 8" in Les miracles de Nostre Dame, which reads "Rose des roses, fleur des fleurs." 18 While Gautier uses the same literary figure, he does it to stress Mary's divinity in an unambiguous religio-political context, for in stanza two Gautier continues explicitly denominating Holy Mary as the "imperial maiden, mother of Christ," and in stanza three, She appears as Mother of God from whom spiritual blessings flow (1-16). ${ }^{19}$ This type of religiously explicit rhetoric, however, does not exist in Alfonso's Cantiga 10. And, while many scholars see Gautier's poem as a possible source for the CSM's Cantiga $10,^{20}$ the poet in the CMS composes his poem as he would a love lyric with but a hint of Mary's divinity in his

1261 when Alfonso held the most hope of realizing this dream.

${ }^{17}$ Alfonso, "Prologo A," Mettmann, 25-28.

${ }^{18} \mathrm{M}$. Chailley believes that Gautier wrote the Miracles between 1233 and his death in 1236, certainly well within Alfonso's lifetime. Quoted in V. Frederic Koenig, introduction to Les Miracles de Nostre Dame, ed. V. Frederic Koenig (Geneva: Droz, 1955), xiv.

19 "Le fleurs dont chant /... / C'est la pucele emperïalz / Qu'apelons mere Jesu Crist, / ... / Mere Dieu," Gautier Miracles, 9, 13-14, 17. [The flower for which I sing / ... / Is the imperial maiden / Whom we call the mother of Jesus Christ, / ... / Mother of God.], Gautier de Coinci, "I Chanson," Les miracles de Nostre Dame, ed. V. Frederic Koenig, 44-46.

${ }^{20}$ Kathryn A. Duys, for instance, underscores the long-held view that Old French literary works inspired later French works as well as those from the Iberian Peninsula. She goes on to state that Gautier was the "primary influence of Alfonso the Wise and his great collection of miracle songs 'Las Cantigas de Santa Maria' (1), and that Alfonso may have had in mind Gautier's song "Quant ces florets florir voi," a song rich in Marian flower imagery, when composing Cantiga 10, "Rosa das rosas" (10). "The "Miracles de Nostre Dame' of Gautier de Coinci," in Teaching Medieval Lyric with Modern Technology (South Hadley, MA: Mount Holyoke College, 2001). 
glosses; moreover, She would not bestow blessings per se, instead, as we see below, the favors the poet seeks are expressed in terms of the mercies a courtly lady would confer upon her lover.

While the poetic voice of the CSM presents sentiment, Alfonso as compiler further contextualizes it within a courtly world through visual representation. To that end, each cantiga in the Códice Rico, MS. T I.1, is accompanied by three rows of two miniatures each in picture book format, complete with captions that would condition the interpretation of the text on the facing folio. ${ }^{21}$ Gazing at these miniatures reminds the reader of the "important function [of] imperial discourse in which paintings and statues have often been created," and that, as political artifacts, miniatures such as these can be seen as "allegories of imperial power" that promote ideology, as Ashcroft et al. assume. ${ }^{22}$ On the other hand, these miniatures cannot categorically be reduced just to political discourse as they can be used to study other facets of culture. For instance, Connie Scarborough, whose study focuses on women in thirteenth-century Spain as portrayed in the CSM, indicates that five of the six miniatures that illustrate Cantiga 10 depict Mary's feminine and divine attributes. In the first miniature, Scarborough rightly sees a Virgin Mary as a woman in a thicket of rose bushes that corresponds to the opening line "Rosa das rosas." ${ }^{23}$ Yet, the first miniature's caption clearly states, "Como Santa Maria e rosa das rosas." ${ }^{24}$ Taking this caption literally, Mary, then, may also be read as a Rose (a personified object) among roses, embodying all the physical and symbolic qualities of a rose par excellence.

The metaphorical expression of this excellence as an inherent quality is perhaps best articulated by thirteenth-century Middle Eastern botanical literature in which the rose's properties are personified with feminine traits: ${ }^{25}$

\footnotetext{
${ }^{21}$ All miniature images described are from Edilán's 'Códice Rico' facsimile and will be documented by folio number, column, A or B, and their vertical position, 1, 2 or 3, along with the ms. shelf number. For example, T.I.1, fol. 18r, A1 would designate the first image (1) in column A on folio 18r. of ms. T.I.1. Alfonso X, Cantigas de Santa Maria: Edición Facsimil del Códice T.I.1., ad passim.

${ }^{22}$ Ashcroft, Griffiths and Tiffin, eds., Post-Colonial Studies, 9-10.

${ }^{23}$ Connie L. Scarborough, Women in Thirteenth-Century Spain as Portrayed in Alfonso $X$ 's Cantigas de Santa Maria (Lewiston, NY: Mellen, 1993), 26.

${ }^{24}$ Alfonso, Cantiga 10, T.I.1, fol. 18r, A1.

${ }^{25}$ Charles Joret, La rose dans l'Antiquité et au Moyen Age: historie, légendes et
} 
In exhaling her perfume, the rose announces her sweet arrival and so expresses herself by its [silent] muted language [. . .]: I fill with fragrance the one who breathes my breath; I impart a concealed [secret] emotion to the innocent beauty who would receive me directly from her lover. ${ }^{26}$

Here, the rose is not a passive flower; instead, personified as a mediatrix, she, as a feminine entity, intercedes on behalf of the male lover in affairs of love, while appropriating the essential nature in appearance and deportment of a sensual young maiden:

The most beautiful of flowers. She is the queen [. . . She is like a timid virgin, she conceals her head, reddened, enveloped in verdure. Her half-opened bud resembles the lips of a young beauty who presses them while kissing her lover. ${ }^{27}$

Describing the greatest of flowers, the author, who re-appropriates terms that describe femininity to convey sentiment through a concept accessible to his readers, animates an object, a rose, that would yield to the desires of a possessor, while displacing women as persons from this type of sensual relationship.

This descriptive language, typical of the verses of the well-known Persian Anwari, is then appropriated once more and infused with sensual sentiment by Middle Eastern poets in the discourse by which male lovers speak of desirable females as botanical specimens by using images like the rose or the synecdochicrose petal. Joret comments:

They are like roses in beauty; their foreheads as well as their ears are roses or rose petals; their cheeks are as delicate as the rose, as are their lips and their countenance, as they [the loved ones] radiate gloriously as the rose. [. . .] Her mouth and the lips are as the rose buds, and their cheeks like the roses of Eden;

symbolism, 1892 (Geneva: Slatkine, 1993), 209-10. All translations of Joret's texts are mine.

${ }^{26}$ Joret points to Azz Eddin-el Mocaedessi's moral allegories: "En exhalant son parfum, la rose m'annonça sa douce venue et s'exprima ainsi dans son language muet: Je suis l'hôte qui vient entre l'hiver et l'été et ma visite est aussi courte que l'apparition du fantôme nocturne; . . . J'embaume celui qui respire mon haleine; Je cause à l'innocente beauté qui me reçoit de la main de son ami une émotion inconnue," Joret, La rose, qtd. in Joret, 210.

27 "Elle en est la reine. . . . Semblable à une vierge timide, elle cache sa tête, en rougissant, dans une enveloppe de verdure. . . . Son bouton qui s'entr'ouvre ressemble aux lèvres d'une jeune beauté qui s'apprête à donner un baiser à son ami," Joret, La rose, 212. 
they compare to a bouquet of rose buds; lastly, their mouths and lips resemble a smiling red rose. ${ }^{28}$

This descriptive rhetoric of sensual love, voiced in terms once used to animate a rose, is crafted into a discourse that objectifies the female. Once objectified, this image becomes pliable in the hands of a rhetorician who can expound an ideology of beauty, love, and power by means of allegory.

Alfonso accomplishes a similar feat by linking written verse to explicatory miniatures, as he begins Cantiga 10 by dedicating four of six miniatures to illustrating Mary's persona. ${ }^{29}$ Cantiga 10's significance is further underscored by the fact that this correlation visually and textually establishes the poem's theme and meter. The first miniature graphically illustrates the first literary figure in the first hemistich in verse one: "Rosa das rosas." The reader sees the visual image of objectified beauty appropriated from an aesthetic ideology typical of the Middle Eastern sensibilities described above. As rose, queen of flowers, Mary is the superlative expression of synthesized beauty, spiritual and sensual. ${ }^{30}$ Within this framework and with the initial three words of the lyric, Alfonso sets the theme and tenor for both refrain and cantiga. Mary is neither mother nor spouse of God, being that Cantiga 10 makes no explicit religious references as does Gautier. Rather, Mary is depicted, foremost, as an object of man's love since the expressions of her qualities are appropriated from Occitan and Galician-Portuguese love lyric and not from the religious rhetoric associated with theological discourse.

On the transformation of courtly expressions from the secular to the sacred, Moshé Lazar comments that with the latter twelfth century there begins a process of "psychological inhibition and repression" that affects troubadour and trouvère love lyric. A "trend toward spiritualization and allegorization" eventually leads to the transfer of "some aspects of the

\footnotetext{
28 "Ils comparent leur amie à une rose ou même à une feuille de rose ; c'est pour eux une rose de beauté; ils parlent des roses de son front et même de ses oreilles, de la rose délicate de ses joues, de ses lèvres et de son visage, de l'émail rose de ses joues, même de son éclat glorieux de roses. Sa bouche et ses lèvres sont pour eux comme un bouton de rose, ses joues comme les roses de l'Éden. Ils les comparent à un bouquet de roses entro'vertes ; pour eux enfin sa bouche et ses lèvres ressemblent à une rose vermeille qui sourit," Joret, La rose, 217

${ }^{29}$ Here I mean it in the sense of the aspect of a person's character that is displayed to, or perceived by, others.

${ }^{30}$ The miniature's caption reads: "Como Santa Maria e rosa das rosas" [How Holy Mary is Rose of roses].
} 
courtly vocabulary" to love hymns addressed to Mary; "our Lady" replaces "my lady" and "midons" of the troubadours. "Within the thirteenth-century's "changing cultural context," poets begin to compose "divine love" songs:

True love and good love, fair body and sweet face, kisses and embraces, desire and joy, garden of delights and dying from passionate love, are so many expressions recuperated from the troubadours' vocabulary by the devotional hymns to Mary, but totally emptied of their profane erotic and sexual connotations. ${ }^{32}$

Any remaining "latent eroticism" would be common to "all mystical love literature" which "sublimated, spiritualized, and allegorized" human love. ${ }^{33}$ While Lazar's observations might generally be true, it is difficult to see Cantiga 10 as devoid of secular content since its language underscores Mary's humanity by using the same precise courtly terminology as do Alfonso's secular love songs which are well documented in Cancioneiro da Biblioteca Nacional. ${ }^{34}$ The same lyric language is exploited for its explicit sexual expressiveness in Alfonso's thirty-two bawdy and salacious contributions to the Cantigas d'escarnho $e$ de mal dizer compiled by Manuel Rodrigues Lapa, the most by any single poet in that collection. ${ }^{35}$

Given such language, and crucial for re-defining Mary's image in Cantiga 10, Alfonso cannot let ambiguity become the agent of misinterpretation since the specificity of the language would allow for "profane erotic and sexual connotations," as Lazar would say. We would propose that since Alfonso understands that the written word alone

\footnotetext{
${ }^{31}$ While Mary in one sense becomes a cross-cultural iconic figure common to Western Europe, she also retains a personal dimension in the transference of "my lady" - $[m i] m a$ dona [domna, dompna] - to an epithet with qualities or attributes characteristic of feminine compassion and grace: she becomes known as the "Madonna"_- "my lady." See Moshé Lazar, "Fin'amour," in A Handbook of the Troubadours, ed. F .R. P. Akehurst and Judith M. Davis (Berkeley: University of California Press, 1995), 61-92. For an in-depth treatment of fin amor, see Moshé Lazar, Amour courtois et "fin'amors" dans la littérature du XIle siècle (Paris: Klincksieck, 1964).

${ }^{32}$ Lazar, "Fin 'amour," 91-92.

${ }^{33}$ Lazar, "Fin'amour," 92.

${ }^{34}$ Elza Paxeco Machado and José Pedro Machado, eds., Cancioneiro da Biblioteca Nacional, antigo Colocci-Brancuti (Lisbon: Revista de Portugal, 1949-1964), 177.

${ }^{35}$ As indicated by the author index, Manuel Rodrigues Lapa, ed., Cantigas d'escarnho e de mal dizer dos cancioneiros medievais galego-portuguese, 2nd ed. (Vigo: Editorial Galaxia, 1970), 639.
} 
cannot adequately express the refrain's authorial intent, and to minimize misreading, images on the folio facing the lyric would serve to make a distinction between the sacred and the profane, clarifying the poet's message and, in doing so, predisposing interpretation of the text. ${ }^{36}$

Keeping this in mind, we see that to the second hemistich of the refrain's first verse there corresponds a second miniature that depicts Mary as the "Flower of all flowers"(10:2), a visual representation that informs the reader of the kind of flower Mary embodies: ${ }^{37}$ the lily, white and pure. Here, though, the lily cannot literarily represent purity ${ }^{38}$-as one might expect of the divine Holy Mary-for verse 4 belies this by glossing both lyric and miniature, stating that this Lily-Mary is the flower, superlatively, of joy and pleasure, or delight:

e fror d'alegria e de prazer (10:4)

[and flower of joy and pleasure/delight]

"Joy" and "pleasure" are typically rewards and mercies sought by entendedors and troubadours from their ladies, favors conferred upon them from domnas at court.

This figure of the domna is precisely what is underscored in the second verse of the refrain, which, when repeated after each glossing stanza, acquires new nuances:

Dona das donas, sennor de Sennores

[Dame ${ }^{39}$ of dames ${ }^{40}$ Lady of ladies]

36 We point out that the illustrations limit full translations of the work into other languages. While visual images may be described, they cannot convey the same sense in a textualized context; describing something cannot replace the visual experience, nor its context.

${ }^{37}$ Alfonso, Cantiga 10, T.I.1, fol. 18r, B1.

${ }^{38}$ Mary 'is addressed as 'lily of the valley' and 'rose of Sharon.' In pictures of the Annunciation, Gabriel greets her with a lily staff, and its heady perfume, filling her chamber, symbolizes her incorruptibility." Warner, Alone, 99.

39 "dame: A female ruler, superior or head: = 'lady', as fem. of lord ('our most gracious Sovereign Lady, Queen Victoria'); the superior of a nunnery, an abbess, prioress, etc." ("dame, I, n.1" in The Oxford English Dictionary. 2nd ed., 1989. OED Online. 10 Dec. $2004<$ http://dictionary.oed.com/cgi/entry/50057307>).

40 "lady": "A woman who rules over subjects, or to whom obedience or feudal homage is due; the feminine designation corresponding to lord. Now poet. or rhetorical, exc. in lady of the manor. In OE used spec. (instead of cwén, QUEEN) as the title of the consort of the king of Wessex (afterwards of England)." "lady, I, n.2," OED Online, 2nd ed., 1989. <http://dictionary.oed.com/cgi/entry/50128889>. Accessed 10 December 2004. 
To assure that the reader can distinguish a "dona" from a "sennor," the third miniature glosses the first hemistich of the refrain's second verse, clarifying what Alfonso means by "Dona," who here is not Holy Mary represented as Madonna with child. Rather Dona-Mary, considerably larger and enthroned, is seated in the center of her entourage, among stylish aristocratic women represented smaller in stature in courtly dress, apparently holding court as they gaze admiringly at her. The ladies in this frame, including Mary, typify those at court who would be recipients of troubadour songs that would praise them and solicit favor and "merce."41 Verse 5 of Cantiga 10 glosses: "'Dona' by being very merciful-'mui piadosa seer.",42 "Piadad," pity, synonymous with "merce" and the object of the poet-lover's supplication of the domna, ${ }^{43}$ is an indispensable element of love and as such an essential feminine quality, as Glyniss Cropp would say; ${ }^{44}$ it designates what René Nelli would call "the compassionate love a woman has for a man," 45 recompense for the lover's suffering. This femininity brings with it power, as illustrated in the miniature that follows.

The fourth miniature glosses the second hemistich of the refrain's second verse. As "Sennor"-literally "lord, or lady as liege — a crowned Mary is seated among other crowned ladies, crowned and in stately dress, women as authoritative expressions of power, She again larger in size and enthroned. The caption reads: "Como Santa Maria e Sennor das sennores" ["How Holy Mary is Queen of queens"], ${ }^{46}$ indicating that Mary possesses the power to relieve affliction, torment, and pain:

Sennor en toller coitas e doors

[lady (as in liege) in taking away suffering and pain] ${ }^{47}$

\footnotetext{
${ }^{41}$ Alfonso, Cantiga 10, T.I.1, fol. 18r, A2.

42 "Dona en mui piadosa ser," Alfonso, Cantiga 10, verse 5.

${ }^{43}$ Cropp, Le vocabulaire, 175.

${ }^{44}$ Cropp, Le vocabulaire, 176.

${ }^{45}$ René Nelli, L'érotique des troubadours (Toulouse: Édouard Privat, 1963), 227.

${ }^{46}$ Alfonso, Cantiga 10, T.I.1, fol. 18r, B2. Joseph F. O'Callaghan prefers the term liege to signify that power, to show Mary as a superior to whom one owes feudal allegiance and service or liege lord. Joseph F. O'Callaghan, Alfonso X and the Cantigas de Santa Maria (Leiden: Brill, 1998), 16. The same terminology is used to refer to the relationship the Domna has with her lover.

${ }^{47}$ As the caption for the image in T.I.1, fol. 18r, A3 reads.
} 
Suffering and pain, "coitas e doores," in courtly terms, abstractly would qualify a lover's condition, as it underscores the torment and affliction suffered by those who serve, and in this context are terms consistent with the ideology used in medieval love lyric as a pretext for the lover to solicit "piedad"- "merce"- from a lady for whom he pines and to whom he devotes himself. In the image under this caption, A3, Mary occupies center stage, flanked on her left and her right by two helper angels. To her right are pictured men in reclining postures and in various states of undress, in agony and gazing pleadingly at her. She, in center stage, confers her mercies ('merces') on them, and on her left are fully restored, upright, and fully dressed men, who have already received her mercies.

The fifth miniature helps to mitigate the images that the lyric might invoke: ${ }^{48}$ with angels present in the background, though not actively involved, it pictures supplicant men stricken by the woes that originate with the wiles of woman, if we take Cantiga 130 into account, for which a crowned Mary — symbol of empire and power-offers relief.

Loving such a Mistress-Queen, Liege-affords protection from all pain and suffering, as She would forgive any man's "sins" arising from base desires if he were found to be deserving:

... que de todo mal o pode guardar;

e pode-1l' os peccados pedõar, que faz no mundo per maos sabores. (10:10-12)

[...that she can guard you against all evil and can forgive all your defects/indiscretions/faults that everyone commits because of desire (literally, poor taste)]

We must note, however, that since only Christ has the power to forgive sin in a spiritual sense, the sins referred to here- "peccados"-must imply the sins Mary can forgive: imperfections, indiscretions, or an offense, a fault. ${ }^{49}$ Here, the act of sinning itself- "pecar"-implies

\footnotetext{
${ }^{48}$ In the Cantigas de escarnho e mal dizer, we find "Santa Maria" playing a role in licentious unions, cantigas $164,165,169,177$. There are also numerous references to help received or implored from "Nostra Sennor" in procuring physical relief from sexual desire. Including the word play with the name Maria, the examples from the Cantigas de escarnho y mal dizer; to name a few, cantigas 1 and 11 , are attributed to Alfonso $\mathrm{X}$. A few additional examples include, cantigas 63, 14, 167, 169, 171, 195, 208, 245, 271, 315, 358, 367, 384, 385, 386, 400, Rodrigues Lapa, Cantigas, ad passim.

${ }^{49}$ pecado: "defecto, culpa, delito, crimen [defect, guilt, misdeed, crime]," Esteban Terreros y Pando, Diccionario castellano (Madrid: Impr. de la viuda de Ibarra, hijos y compañia, 1786-1793), s.v. "pecado."
} 
noncompliance with any obligation of what is just and necessary in the rules of art and politics, as well as in the rules of love, ${ }^{50}$ which might include committing "maos sabores" that Rodrigues Lapa would define as "pleasure, satisfaction, desire, seduction," 51 precisely what a "piadosa" lady would forgive. Since neither text nor image reveals a mediatrixMary interceding with God on behalf of man, Mary directly relieves man's desire and distress. However, this "merce," this act of "piadat" comes with one proviso: it is reserved for the deserving man, one who would love_- "amar"-and serve_-"servir"- - her. Such a man she would keep from foolishness and sinning, and from committing indiscretions. (10:14-17).

These terms of endearment, signs in courtly ideology for commitment, love, sex, etc., have not merely suffered transference from the profane to the sacred. Specific, personalized language has been stripped from any connotations of womanly qualities and has been reappropriated to Mary for the specific and personal gain of the poet. Earthbound women in courtly settings, and not in league with Mary, are left lacking descriptors for the natural gifts of feminine worthiness that twelfth-century Occitan love lyric, which gave rise to such language, emphasized.

By re-contextualizing the transformed language of fin'amors, Alfonso crafts the persona of Mary in Cantiga 10 by inscribing in her the qualities of the "dona" whose troubadour he would aspire to be, for whose love he would leave all other loves-lustful women by nature - to the devil:

se eu per ren poss' aver seu amor, dou ao demo os outros amores. (10:20-21)

[if (only) I for some reason could have her love, I (would) resign to the devil (all) the other loves]

As a guarantee of faithfulness, Alfonso willingly resigns all other love affairs - evil passions - embodied in earthbound courtly ladies whom he

${ }^{50}$ Pecar: "2. Faltar de cualquier obligación y a lo que es debido y justo, o a las reglas del arte o política," in comps. and eds. Lloyd A. Kasten et John J. Nitti, Diccionario de la prosa castellana del Rey Alfonso X (New York: Hispanic Seminary of Medieval Studies, 2002), s.v. "pecar."

${ }^{51}$ Sabor: "prazer, satisfação; desejo; sedução [pleasure, satifaction, desire, seduction]," in Rodrigues Lapa, "Vocabulario Galego-Português," Cantigas, 90, s.v. "sabor"; worldly behavior unbecoming to Mary. 
would consign to the "demon," the Devil. Underscoring this commitment, the last miniature shows a black demon, urging two festively dressed ladies (one of them on his arm) towards a half open door, as Alfonso, kneeling before the Virgin, chooses Mary with his right index finger while looking back towards demon and ladies and banishing them from Her presence with his left—sinister-hand. ${ }^{52}$ Alfonso's pledge bolstered by the action in the last miniature willfully imprecates ${ }^{53}$ woman-kind with the personified agency of demonic sexual depravity as it foreshadows woman's role in the demise of man - as seen in Cantiga $185 .^{54}$ Woman, in the role of mother-in-law, is complicit, with demonic forces, in the designs of depravity personified in a black male, as seen in Cantiga 185 and discussed below. ${ }^{55}$

For the sake of an idealized masculine construct-a Rose-MaryAlfonso forsakes courtly women of flesh and blood, thereby categorically consigning them, with his left hand, to a perpetually transgressive state, while simultaneously pointing up at Mary with his right, underscoring the opposing qualities between the Holy and the depraved. We see this opposition more fully articulated in Cantigas 60 and 130 which drive home the point with a "repertoire of contrasts standard to Marian songs [that] reiterate the sharp division between Mary and Eve." Eve, then, becomes an icon of sin, "as [do] by extension all her [female] descendants," while Mary, "the one woman who escaped the taint of original sin," ${ }^{, 56}$ remains exempt from sin. To a lesser extent, Cantiga 10 is also inflected by that contemporary masculinist bias that falsely represents woman as inherently subordinate and evil, while promoting the opinions and values of men.

How the representation of woman promotes the construct of the sexualized female body is reinforced in the last miniature in Cantiga 10 in the presence of the male black demon, an image regularly included in many of the miniatures in the Códice Rico. In this case, though, both image and text designate the demon as an explicit sign of illicit sexual activity. Women in the presence of the black demon, and sometimes in

\footnotetext{
${ }^{52}$ Alfonso, Cantiga 10, T.I.1, fol. 18r, B3.

${ }^{53}$ I am using the definition "imprecate 4 ....To invoke evil upon (a person); to curse." OED Online, July 2018, www.oed.com/view/Entry/92672. Accessed 2 November 2018.

${ }^{54}$ Alfonso, Cantiga 185, T.I.1, fol. 244r, A1, B1.

${ }^{55}$ Alfonso, Cantiga 185, T.I.1, fol. 243r, ad passim.

${ }^{56}$ Scarborough, Women, 33.
} 
the presence of black male Moors, become allegorical figures for deviant sexuality in the CSM. However, women in and of themselves can be the cause of men's indiscretions. Cantiga 130, for instance, explicitly outlines how "donas" cause their male courtly lovers to sin and to fall into torment and affliction (130:9). The first of the six miniatures accompanying this cantiga portrays three men breaking their gaze from Mary and casting it on courtly women in festive dress; other men in the miniature hold their gaze firm on Mary. ${ }^{57}$ These indiscrete, suffering males would not be eternally damned for their sexual indiscretions, but are shown to be worthy of Mary's grace-_merce"-while others, unbefitting of the court, can never merit this favor.

This last miniature in Cantiga 10 is a material example of sexual otherness that becomes instrumental in the construction of a transgressive female sexuality by associating it with racial blackness that signifies transgressive sexual behavior linked to racial otherness. Cantiga 185 of the Códice Rico underscores this transgressive sexual behavior by relating how a jealous mother-in-law maligns her son's new bride. One day she sends her Moorish servant to lie next to her sleeping daughter-inlaw. ${ }^{58}$ She then accuses her innocent daughter-in-law before her son ${ }^{59}$ and the magistrate who, ${ }^{60}$ before witnesses, would condemn the deed:

... "Que sera

Daquesta moller que tan gran torto fez

Que desconnoceu Deus e o mund' e prez, que fez feito mao, vil e tan rafez?

E por aquesto no fogo ardera. (185:41-46)

[..."What will become

of this woman who commits such great wickedness, who repudiated God and mankind and virtue, who has committed an evil, vile, and such a contemptible deed? And for this in fire she will burn]

\footnotetext{
${ }^{57}$ Alfonso, Cantiga 130, T.I.1, fol. 184r, A1.

${ }^{58}$ Alfonso, Cantiga 185, T.I.1, fol. 244r, A1.

${ }^{59}$ Alfonso, Cantiga 185, T.I.1, fol. 244r, B1.

${ }^{60}$ Alfonso, Cantiga 185, T.I.1, fol. 244r, A2.
} 
Though I will not here comment on the overtly racist lyric and images of the text, the miniatures that accompany this cantiga do portray a black kinky-haired moor, racially distinct from the fair complexioned, fair-haired personages who represent the norm. The juxtaposed black man and fair maiden lying side by side underscore the implied abhorrent sexual transgression that must be purged with fire. This juxtaposition is played out in the second to the last miniature that accompanies this cantiga, which portrays two burning stakes. On the right, the moor is being consumed by fire, but the burning stake on the left contains no one. Between both flaming stakes, the maiden remains untouched by the flames with a crowned Mary's hands - directly behind the maidenplaced on her shoulders. ${ }^{61}$ Mary's power, signified by the crown, and grace saves the young wife, but the moor "who was as black as pitch" [que era tan / negro come pez] perishes by fire $(185: 60-61,65)$.

Whereas the individual woman in Cantiga 185 is saved by invoking Mary's grace, the women in the last miniature of Cantiga 10, who categorically represent all naturally sensual women, have no option, no redeeming grace. They are left to ravish and be ravished by the devil as they bodily become part and parcel of things demonic. ${ }^{22}$ The bodies of these doomed women, then, become part of a construct that allegorizes woman's transgressive condition that must be absolved or purged so that the male may be rewarded. By extension, all women's bodies (descendants of Eve) are directly constructed as part of a transgressive sexuality, as bodies also become a site of discourse of a different kind. Moreover, taking Cantiga 10 as a whole, earthbound women are perceived reductively as not only sexual but also reproductive subjects, wombs of sin, whose function is limited to populating the world with sinners. They are no longer the "donas" who graced the courts, objects of man's desire that stimulated the composition of lyric song and courtly love.

Thus, the rhetoric of twelfth- and thirteenth-century love lyric that once praised women, elevated women's bodies as well as their sensual and spiritual being to the highest of esteem, is combined with graphic representation of a botanical metaphor that speaks to sensual feminine attributes, typical of Middle Eastern poetic sensibilities for praising women. These modes of expression are then appropriated by an ideology

\footnotetext{
${ }^{61}$ Alfonso, Cantiga 185, T.I.1, fol. 244v, A3.

${ }^{62}$ Alfonso, Cantiga 10, T.I.1, fol. 18r, B3.
} 
of religious and political empire, which would instill those values in an allegorized Mary representing a religionized political system which upholds One Mary as a pliable image used to justify the male-dominated agenda. ${ }^{63}$ Constructed by Alfonso, King of the land and pretender to the Holy Roman Emperorship, the representation in the CSM of this allegory authorizes that one selfsame system that would consign all women seeking sensual love to a powerless and sinful state by measuring woman against an unattainable ideal of impeccability that Mary represents

Earthbound woman can never be like Mary, an idealized male construct, for the Mary in this last miniature, Madonna with Christ child, powerfully influences Alfonso X, her agent and part and parcel of an allegorized agency. This agency condemns all women (not given over to Mary), sinfully sexual beings by nature, to a devil who would ravish them and then turn them loose on the innocent unsuspecting males for whom Alfonso composes his songs; yet, these males too must accept this "dona" and have her as "Sennor" (10:18). This Mary who from the first miniature, as Rose-Mary, is depicted as the maximum expression of sensual beauty, to the last, as Madonna, in which She, through Alfonso $\mathrm{X}$, her agent, powerfully consigns woman to Satan, embodies in Cantiga 10 the Superlative Allegory of Beauty and Power by signifying, as the rubricated incipit indicates, just "How beautiful, good, and powerful" she is ["Esta é de loor de Santa Maria, com é fermosa e bõa e á gran poder"].

\section{Dickinson College}

\footnotetext{
${ }^{63}$ By "religionized" we mean "imbue[ed] with religion, render[ed] religious," as we see any construct of empire in this period of the Middle Ages. See "religionize, v." OED Online, July 2018. www.oed.com/view/Entry/161950. Accessed 2 November 2018.
} 


\section{Bibliography}

Alfonso X, el Sabio. Cantigas de Santa María. Edited and translated by Walter Mettman. Clássicos Castalia 134, 172, 178. 3 vols. Madrid: Castalia, 1986-89. [Prólogo A, 1:53-54; Cantiga 10, I:84-85; Cantiga 60, I:204-05; Cantiga 130, II:86-87.]

-. Cantigas de Santa Maria: Edición Facsimil del Códice T.I.1. de la Biblioteca de San Lorenzo el Real de El Escorial. 2 vols. Madrid: Edilán, 1979. [Cantiga 10, Folios 17v-18r; Cantiga 185, Folios 243v-244r.]

-. Cantigas de Santa Maria. Teaching Medieval Lyric with Modern Technology. Dir. Margaret Switten. Sponsored by The National Endowment for the Humanities and Mount Holyoke College. South Hadley, MA: Mount Holyoke College, 2001. CD 2 disks.

Alfonso X. Songs of Holy Mary of Alfonso X, the Wise: A Translation of the Cantigas de Santa Maria. Translated by Kathleen Kulp-Hill. Medieval \& Renaissance Texts \& Studies 173. Tempe: Arizona Center for Medieval and Renaissance Studies, 2000. [Prolog A, 1.]

Ashcroft, Bill, Gareth Griffiths and Helen Tiffin, eds. Post-Colonial Studies: the Key Concepts. London and New York: Routledge, 2000.

Cropp, Glynnis M. Le vocabulaire courtois des troubadours de l'époque classique. Publications Romanes et Françaises 135. Geneva: Droz, 1975.

Duys, Katherine A. "The 'Miracles de Nostre Dame' of Gautier de Coinci." Teaching Medieval Lyric with Modern Technology. Dir. Margaret Switten. Sponsored by The National Endowment for the Humanities and Mount Holyoke College. South Hadley, MA: Mount Holyoke College, 2001. CD 2 disks.

Gautier de Coinci. "I Chanson." Les miracles de Nostre Dame. Edited by V. Frederic Koenig. Vol. 1, 44-46. Textes littéraires français. Geneva: Droz, 1955.

González Jiménez, Manuel. Alfonso X el Sabio: historia de un reinado, 1252-1284. Corona de España I. Reyes de Castilla y Leon. Palencia: Diputación Provincial de Palencia, 1993. 
Heur, Jean-Marie d'. Troubadours d'Oc et troubadours galiciensportugais. Cultura medieval e moderna I. Paris: Funação Calouste Gulbenkian, 1973.

Joret, Charles. La Rose dans l'antiquité et au moyen âge: histoire, légendes et symbolisme. 1892. Geneva: Slatkine, 1993.

Kasten, Lloyd A., and John J. Nitti, eds. Diccionario de la prosa castellana del Rey Alfonso X. Spanish Series 126. New York: Hispanic Seminary of Medieval Studies, 2002.

Koenig, V. Frederic. "Introduction." Les Miracles de Nostre Dame. Edited by V. Frederic Koenig. Vol. 1, vii-1. Textes littéraires français. Geneva: Droz, 1955.

Lazar, Moché. "Fin'amour." In A Handbook of the Troubadours. Edited by F. R. P. Akehurst and Judith M. Davis, 61-100. Publications of the UCLA Center for Medieval and Renaissance Studies 26. Berkeley: University of California Press, 1995.

-. Amour courtois et "fin'amors" dans la littérature du XIIe siècle. Bibliothèque française et romane, Series C, Études littéraires 8. Paris: Librairie C. Klincksieck, 1964.

Levy, Emil, comp., Petit dictionnaire provençal-français. Heidelberg: Carl Winter, 1973.

Machado, Elza Paxeco, and José Pedro Machado, eds. Cancioneiro da Biblioteca Nacional antigo Colocci-Brancuti. Obras-primas portuguesas 3. 8 vols. Lisbon: Revista de Portugal, 1949-63.

Nelli, René. L'érotique des troubadours. Toulouse: Édouard Privat, 1963.

O'Callaghan, Joseph F. Alfonso $X$ and the Cantigas de Santa Maria : A Poetic Biography. The Medieval Mediterranean 16. Leiden and Boston: Brill, 1998.

Rodrigues Lapa, Manuel, ed. Cantigas d'escarnho e de mal dizer dos cancioneiros medievais galego-portugueses. 2nd ed. Colección Filolóxica. Vigo: Editorial Galaxia, 1970.

Scarborough, Connie L. Women in Thirteenth-century Spain as Portrayed in Alfonso X's Cantigas de Santa Maria. Hispanic Literature 19. Lewiston, New York: Mellen, 1993.

Snow, Joseph T. "The Central Rôle of the Troubadour Persona of Alfonso X in the Cantigas de Santa Maria." Bulletin of Hispanic Studies 56.4 (1979): 305-16. 
Terreros y Pando, Esteban de, et al. eds. Diccionario castellano, con las voces de ciencias y artes y sus correspondientes en las tres lenguas, francesa, latina é italiana. 4 tomos. Madrid: Impr. de la viuda de Ibarra, hijos y compañía, 1786-1793.

Warner, Marina. Alone of All Her Sex: The Myth and the Cult of the Virgin Mary. New York: Knopf, 1976. 